\title{
List of Contributors
}

Caroline Forder

Patty Gerstenblith

Sandy Ghandi

Joanna Goyder

Marion Haunton

Jennifer James

Vassos Karageorghis

Paul Kearns

I. H. Longworth F.S.A
Privaatrecht Faculteit der Rechtsgeleerdheid, Rijksuniversiteit Limburg, Postbus 6166200 MD Maastricht, The Netherlànds. Telephone: $043-887777$ Fax: 043 $2565 \cdot 38$

College of Law, DePaul University, 25 East Jackson Boulevard, Chicago, Illinois, 60604-2287 USA. Telephone: $312-3628701$

Lecturer in Law, Department of Law, University of Reading, PO Box 218, Reading RG6 2AA England. Telephone: 0734318366 Fax: 0734753280

European Co-Ordinator, Baker \& McKenzie, Boulevard du Regent 40, 1000 Brussels, Belgium. Telephone: 32-2 5063611 Fax: 32-2 5116280

Legal Counsel, Department of Communications Legal Services, 300 Slater Street, Ottawa, Ontario K1A OC8, Canada. Telephone: $613-990-4405$ Fax: 613954-1478

Senior Lecturer in Law, Department of Law, University of Reading, PO Box 218, Reading RG6 2AA, England. Telephone: 0734318366 Fax: 0734753280

Foundation Anastasios G. Leventis, 28 Sofoulis St., Chanteclair Bld., Off. 114, Nicosia, Cyprus. Telephone: 02-461706 Fax: 02459090

38 Erw Salusbury, Denbigh, Clwyd, Wales LL16 3HL.

Keeper of Prehistoric and Romano-British Antiquities, The British Museum, London WC1B 3DG, England. Telephone: 0713238293 
Clare Maurice

Patrick J. O'Keefe

Linda Pinkerton

Lyndel V. Prott

Kurt Siehr

Richard Turnor
Partner, Allen and Overy, 9 Cheapside, London EC2V 6AD, England. Telephone: 0712489898 Fax: 0712362192

6 Villa des Entrepreneurs, Paris 75015, France

J. Paul Getty Trust, Secretary and Trust Counsel, 1875 Century Park East Suite 2300, Los Angeles, California 90067-2561 USA. Telephone: 213277 9188 Fax: $213-5568215$

Head of the International Standards Section, Cultural Heritage Division, UNESCO, 7 Place de Fontenoy, Paris 75015, France. Telephone: 45684440

Frohburgstrasse 52, CH-8006, Zürich, Switzerland. Telephone: 013640255

Partner, Allen and Overy, 9 Cheapside, London EC2V, England. Telephone: 071 2489898 Fax: 0712362192 


\section{Index to Volume One}

\section{Table of Contents}

\section{Articles}

Gurr, Andrew, "Cultural Property and 'Sufficient Interest': the Rose and the Globe Sites"

Hubert, Jane, "Dry Bones or Living Ancestors? Conflicting Perceptions of Life, Death and the Universe"

Karageorghis, Vassos, "The Trade in Cypriot Antiquities in London"

Lowenthal, David, "Counterfeit Art: Authentic Fakes?"

Maurice, Clare and Turnor, Richard, "The Export Licensing Rules in the United Kingdom and the Waverley Criteria"

Merryman, John Henry, "Counterfeit Art"

Pinkerton, Linda, "The Native American Graves Protection and Repatriation Act: An Introduction"

Prott, Lyndel and O'Keefe, Patrick, " 'Cultural Heritage' or 'Cultural Property'?"

Siehr, Kurt, "The UNIDROIT Draft Convention on the International Protection of Cultural Property"

\section{Book Reviews}

Blutke, Günter, Obscure Business with Art and Antiques. A Criminal Report (Kurt Siehr)

Goodman, David and Redcliff, Michael, (eds.) Environment and Development in Latin America: The Politics of Sustainability (Nicola Atkinson)

Hiller, Susan, (ed.) The Myth of Primitivism: Perspectives on Art (Brad Sherman)

O'Keefe, P.J. and Prott, L.V., Law and the Cultural Heritage Volumes 1 and 3 (Geoffrey Lewis)

Price, Sally, Primitive Art in Civilised Places (Brad Sherman)

\section{Case Notes}

Byrne-Sutton, Quentin, “The Goldberg Case: A Confirmation of the Difficulty in Acquiring Good Title to Valuable Stolen Cultural Objects" 
Debattista, Charles, "Authenticity, Merchantable Quality and the Sale of Goods by Description"

Ghandi, Sandy and James, Jennifer, "The God That Won"

Gerstenblith, Patty, "Guggenheim v Lubell"

$369-381$

Goyder, Joanna, "Scheduling Monuments: The Rose Theatre Case"

Kaye, Peter, "International Jurisdiction Over Companies: When is an Art Gallery not an Art Gallery?"

Kearns, Paul, "Not a Question of Art: Regina v Gibson Regina v Sylveire"

McKendrick, Ewan, “Auctioneers, 'Sleepers' and Actions in Negligence"

$359-367$

$353-358$

$185-192$

$383-388$

Merryman, John Henry, "Limits on State Recovery of

Stolen Artifacts: Peru v Johnson"

$207-213$

O'Keefe, Patrick, "Maoris Claim Head"

Prott, Lyndel, "Movables and Immovables as Viewed by the Law"

Redmond-Cooper, Ruth, "Defamation and the Art World"

Shiina, S., "The Iba Site Case"

Siehr, Kurt, "Manuscript of the Quedlinberg Cathedral

Back in Germany"

Ward, Alan, "Treasure Trove and the Law of Theft"

$169-173$

$393-394$

$389-392$

$175-183$

$193-194$

$215-217$

$195-198$

\section{Chronicles and Events}

September 1990-August 1991

$143-149$

September 1991-March 1992

$343-352$

\section{Conference Reports}

Dyer, Christopher, "Art Antique and Architectural Theft Conference held by the Georgian Group and Trace" 15-17 November 1990 Plymouth

Tauber, Christoph, "The International Protection of Cultural Property sponsored by the Austrian Academy of Sciences" Vienna 18-19 October 1990

Wyss, Martin Phillip, "The Protection of the Cultural Heritage and its Legal Dimensions: The Heidelberg Symposium" 22-23 June 1990

\section{Correspondence}

Elsen, Albert, "The Elsen/Walsh Controversy"

\section{Documents}

Forder, Caroline, "Treasure Trove in the Netherlands: Article 13 of Book 5 of the New Dutch Civil Code"

Kemp, Martin, "The 'Guidelines for the Professional Practice of Art History' Issued by the Association of Art Historians in Great Britain" 
Proposal for Council Regulations (EEC) on the Export of Cultural Goods

Siehr, Kurt, "Preliminary Draft Unidroit Convention on Stolen or Illegally Exported Cultural Objects (approved by the UNIDROIT Study Group on the International Protection of Cultural Property at its Third Session on 26 January 1990)"

\section{Essays}

Agnew, Julian, and Farrar, Matthew, "Goya's 'Marquesa de Santa Cruz""

Longworth, Ian, "Snettisham Revisited"

\section{Legislation}

Forder, Caroline, "New Treasure Trove Law in the Netherlands"

Haunton, Marion, “Canada's Proposed Archaeological Heritage Protection Act"

Pinkerton, Linda, "The Native American Graves Protection and Repatriation Act"

\section{Treaties and EC Matters}

Goyder, Joanna, "European Community Free Movement of Cultural Goods and European Community Law"

- Part I

- Part II

Table of Statutes

\section{United Kingdom}

Ancient Monuments and Archaeological

Areas Act 1979

Copyright Acts 1911, 1956, 1988

9 et seq., 353 et seq.

244

Import, Export and Customs Powers (Defence)

Act 1939

$274-275,283$

Limitation Act 1980

National Heritage Act 1983

Sale of Goods Act 1979

Supreme Court Act 1981

$372-372,378-379$

9 et seq., 353 et seq.,

199 et seq.,

Town and Contry Planning Act 1971

$22-23$ 


\section{United States}

Archaeological Resources Protection Act 1979

California Art Preservation Act 1979

Copyright Act 1978

Cultural Property Implementation Act $1983 \quad 27$ et seq.,

Model Penal Code (American Law Institute Draft Text

and Commentaries) Washington D.C. $1967 \quad 48-50$

Native American Graves Repatriation Act $1990 \quad$ 297-305

New York Artists' Authorship Rights Act 1983

\section{Others}

Aboriginal and Torres Strait Islander Heritage Protection Act (Australia) 1984

Administrative Proceedings Act (Japan)

$193-194$

Civil Code (Netherlands) 1838, 1992

Constitution Act (Canada) 1867

$396-401$

Heritage Commission Act (Australia) 1975

395

319

Monuments Act (Netherlands) 1988

$397-401$

New South Wales Heritage Act (Australia) 1977

Protection of Movable Heritage Act (Australia) 1986

Tamil Nadu Hindu Religious and Charitable

Endowments Acts (India) 1959, 1976

319

Treasure Trove Act (India)

372 et seq.,

372 et seq.,

\section{Table of Cases}

\section{United Kingdom}

Arab Monetary Fund v Hashim and Others (No.3) (1991)

Attorney-General for the Duchy of Lancaster v GE Overton (Farms) Ltd (1980)

Bumper Development Corporation Ltd $\mathrm{v}$ Commissioner

of Police for the Metropolis and Others (1991)

Cleveland Museum of Art $\mathrm{v}$ Capricorn International SA and Another (1990)

Emperor of Austria v Day and Kossuth (1861)

Harlingdon \& Leinster Enterprises Ltd v Christopher Hull

Fine Art Ltd (1990)

$199-205$

Hartt v Newspaper Publishing plc and Others 
Hip Foong Hong v Neotia \& Co (1918) 374 Hongkong Fir Shipping Co Ltd v Kawasaki Kisen Kaisha (1962)

Knuller (Publishing, Printing and Promotions) Ltd v Director of Public Prosecution (1972)

Leaf $\mathrm{v}$ International Galleries (1950)

384 et seq.,

Luxmoore-May v Messenger May Baverstock (1990)

Morgan v Odhams Press (1971)

Nevill v Fine Arts and General Insurance Co Ltd (1897)

$R \vee$ Gibson (1990)

$R$ v Hancock (1990)

$383-388$

$R$ v Lemon (1979)

$195-198$

$R$ v Secretary of State for the Environment, ex parte Rose Theatre Trust Co. (1990)

$R \vee$ Sylveire (1990)

383 et seq.,

Re Oriel Ltd (1985)

$10-25,353-358$

$383-388$

187

Shaw v Director of Public Prosecution (1961)

Winkworth v Christie, Manson \& Woods (1980)

383 et seq., 325

\section{United States}

Autocephalous Greek-Orthodox Church of Cyprus v Goldberg (1990)

$151-168$

De Weerth v Baldinger (1987)

Golden Budha Corporation v Canadian Land Company

of America (1991)

360 et seq.

Guggenheim v Lubell (1990)

$362-363$

Hoelzer v City of Stamford

$359-367$

Jeanneret $\mathrm{v}$ Vichy (1982)

(1989)

Kunstsammlungen zu Weimar v Elicofon (1981)

235

Menzel v List (1964)

157 et seq., 360

New York v Wright Hepburn Webster Gallery Ltd. (1970)

O'Keefe v Snyder (1979)

Peru v Johnson (1989)

$41-42$

Regan v Time (1984)

360 et seq.,

$169-173$

Republic of Turkey $v$ Metropolitan Museum of Art (1990)

$U S$ v Hollinshead (1974)

362

US v McClaine (1979)

$171-3$

Wagner v Simon, (1974)

$171-173$

$50-52$

\section{Others}

Arnamagnaean Foundation v Ministry of Education Denmark (1966) (1971)

Fondation Abegg v Ville de Genève France (1988)

Milirrpum v Nabalco Pty Ltd Australia (1971)

$389-392$

Mullick v Mullick India (1925)

Ville de Genève et Fondation Abegg v Consorts Margail

France (1985)

$389-392$ 


\section{Table of Conventions and Treaties}

1907 Hague Convention for Respecting the Laws and Customs of War on Land

1954 UNESCO Convention for the Protection of Cultural Property in the Event of Armed Conflict

$151,234,236$, $247-248,312$

1956 EEC Treaty of Rome $219,325,407-408$ 1968/1978/1989 Brussels Conventions on Jurisdiction and the Enforcement of Foreign Judgements in Civil and Commercial Matters

1969 European Convention on the Protection of the Archaeological Heriţage 1970 UNESCO Convention on the Means of Prohibiting and Preventing the Illicit Import, Export and Transfer of Ownership of Cultural Property

1972 UNESCO Convention concerning the Protection of the World Cultural and Natural Heritage

1973 European Convention on the Protection of the Archaeological Heritage

1985 European Convention on Offences Relating to Cultural Property

1985 Convention for the Protection of the Archaeological Heritage of Europe

1988 Lugano Convention on Jurisdiction and the Enforcement of Foreign Judgements in Civil and Commercial Matters

\section{Subject Index}

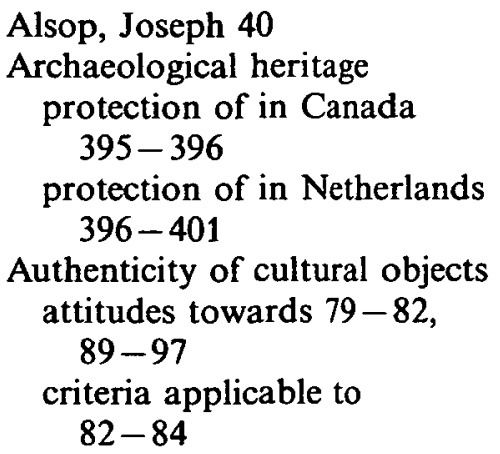

\author{
description of in sale of \\ $199-205$ \\ early music $86-89$ \\ Bailment 363-364 \\ Banfield, Edward 30 \\ Cazenove Frescoes 389-392 \\ Conflict of Law \\ English and foreign \\ 374-377 \\ Kanakaria mosaics and \\ $155-166$
}


lex fori $376-377$

Ownership of Nataraja and $374-377$

rules $189-191$

within the EC 403-411

Counterfeit Art 27-103

authenticity and 79-103

disposal of $57-61$

morality of 34

relationship to counterfeit

money and stamps 50-55

social response to $47-57$,

$61-63$

ubiquity of $43-47$

Cultural heritage

definintion of $307-309$

law and 318-319

Cultural property

problems with usage of $309-312$

law and $312-318$

seizure of by state $429-430$

Cyprus

illegal export from $331-332$

Defamation

art world and 175-183

Defence

of fair comment 182-183

of justification $181-182$

of laches 361,364

Duty 208-211

'due diligence' 361-363

Ethics,

art historians and $239-251$

English Heritage

attitude to Rose and Globe

theatre sites $9-25,355$, 357

Environment

of Latin America 427-428

Export licensing (UK)

$273-295$

funding of $286-288$

indenfinite stop procedure

292-293

'OGEL' 283-284

Free movement of goods in the

EC 219-225, 403-411
'Getty Aphrodite' 129-135

Globe Theatre, London 9-25

'Goldberg Case' 151-168

Good Title

stolen objects and $151-168$

Goya, 'Marquesa de Santa

Cruz' 137-141

Hamilton, Charles 30

Human Remains 105-127, 297-305,

're-burial issue' and $106-110$

repatriation $301,393-394$

'right of possession' $300-301$

trafficking in $304-305$

Vermillion Accord 111-113

Iba Site 193-194

Illegal Exports documentation and $137-141$

from Cyprus $331-332$

UNIDROIT draft convention on $252-255$

Irving, Clifford 30

Kanakaria Mosaics 151-168

Keating, Tom 30, 63, 90 faking of 'Old Masters' $38-41$

Nataraja 369-381

Movables and Immovables $389-392$

Negligence actions in $207-213$

Obscenity

English laws and $383-388$

Quedlinberg Cathedral manuscript 215-217

Primitive Art 423-426

Rose Theatre, London 9-25, $353-358$

Sale of goods $199-205$

Simulationist art $46-47$

'Snettisham Hoard' 333-341

Sufficient interest $9-25$

Stead, Dr Ian 333, 340

Stein, Anne-Marie 30, 34

Stein, David

forgeries by $41-42,47$ 
Stolen artefacts,

Indian legislation and $369-381$

attitude of English courts to 379

limits on state recovery of $169-173$

Treasure trove 195-198, $333-341$

'animus revertendi' $337-339$
Dutch law of 396-401, 413

Indian law of 372 et seq., UNIDROIT draft convention $252-255$, $321-329$

van Meegeren, Hans 90 'problem' of $28-33,34$ et seq.,

Waverley criteria $273-295,408$ 
Treaties and EC Matters

403 Free Movement of Cultural Goods and the European Community: Part II Joanna Goyder

\section{Documents}

413 Treasure Trove in the Netherlands: Article 13 of Book 5 of the New Dutch Civil Code Caroline Forder

415 Proposal for a Council Regulation (EEC) on the Export of Cultural Goods

\section{Book Reviews}

423 Susan Hiller (ed.) The Myth of Primitivism: Perspectives on Art; Sally
Price Primitive Art in Civilised Places Brad Sherman

427 David Goodman and Michael Redcliff (eds.) Environment and Development in Latin America: The Politics of Sustainability Nicola Atkinson

429 Günter Blutke Obskure Geschäfte mit Kunst und Antiquitäten. Ein Kriminalreport [Obscure Business with Art and Antiques. A Criminal Report] Kurt Siehr

431 List of Contributors

433 Index

\section{Preview}

In forthcoming issues of the International Journal of Cultural Property we plan to publish articles on The Movement of Art Treasures to and from Eastern Europe, Antiquities Collecting Policies - an Update, the Treatment and Protection of Antiquarian Treasures in the Middle East, Fiscal Incentives and the Public Donation of Works of Art, and the Unlawful Importation of Illegally Removed Cultural Property into the United States. Our EC and Treaties section will contain a full update on European developments involving art exports and the single market. In addition, there will be case notes, notes of legislation, book reviews and Chronicles. Contributors include Mark Almond, Robert Klein, Gareth Miller, Judith Church, Manlio Frigo and Ian Edge. For further information concerning this and future issues, please contact the Editor in Chief. 


\section{Contents}

Issue 2/1992

269 Editorial

Norman Palmer

Articles

273 The Export Licensing Rules in the United Kingdom and the Waverley Criteria Clare Maurice and Richard Turnor

297 The Native American Graves Protection and Repatriation Act: An Introduction Linda F. Pinkerton

307 'Cultural Heritage' or 'Cultural Property"? Lyndel V. Prott and Patrick J. O'Keefe

321 The UNIDROIT Draft Convention on the International Protection of Cultural Property Kurt Siehr

\section{Opinion}

331 The Trade in Cypriot Antiquities In London Vassos Karageorghis

\section{Essay}

333 Snettisham Revisited Ian H. Longworth F.S.A.

\section{Chronicles}

\section{Case Notes}

353 Scheduling Monuments: The Rose Theatre Case Joanna Goyder

359 Guggenheim v Lubell Patty Gerstenblith

369 The God that Won Sandy Ghandhi and Jennifer James

383 Not a Question of Art: Regina v Gibson Regina $v$ Sylveire Paul Kearns

389 Movables and Immovables as Viewed by the Law

Lyndel V. Prott

393 Maoris Claim Head Patrick J. O'Keefe

\section{Legislation}

395 Canada's Proposed Archaeological Heritage

Protection Act

Marion Haunton

396 New Treasure Trove Law in the Netherlands Caroline Forder

401 The Native American Graves Protection and Repatriation Act Linda F. Pinkerton 